\title{
Action of polystyrene nanoparticles of different sizes on lysosomal function and integrity
}

\author{
Eleonore Fröhlich ${ }^{1,2^{*}}$, Claudia Meindl ${ }^{1}$, Eva Roblegg ${ }^{3}$, Birgit Ebner ${ }^{1}$, Markus Absenger ${ }^{1}$ and Thomas R Pieber $^{2}$
}

\begin{abstract}
Background: Data from environmental exposure to nanoparticles (NPs) suggest that chronic exposure may increase the incidence of lung, cardiovascular and neurodegenerative diseases. Impairment of cell function by intracellular accumulation of NPs is also suspected. Many types of NPs have been detected in the endosomallysosomal system and, upon repeated exposure, alterations of the endosomal-lysosomal system may occur. To identify such effects we compared the effect of carboxyl polystyrene particles (CPS) of different sizes (20-500 nm) on lysosomes of the endothelial cell line EAhy926 after short (24h) and long (72h-96h) exposure times. Lysosomal localization of CPS, as well as lysosomal pH, lysosomal membrane integrity, morphology of the endosomallysosomal system and activities of the lysosomal enzymes,cathepsin B and sulfatases, upon exposure to CPS were recorded.

Results: CPS in sizes $\leq 100 \mathrm{~nm}$ showed high co-localization with lysosomes already after 4h, larger CPS after 24h. None of the particles at non-cytotoxic concentrations caused marked changes in lysosomal pH or destroyed lysosomal membrane integrity. At 24h of exposure, $20 \mathrm{~nm}$ CPS induced significant dilatation of the endosomallysosomal system and reduced activity of lysosomal sulfatases. After $72 \mathrm{~h}$, these alterations were less pronounced.

Conclusions: Despite accumulation in lysosomes CPS induced only small changes in lysosomes. Upon longer contact, these changes are even less pronounced. The presented panel of assays may serve to identify effects on lysosomes also for other NPs.
\end{abstract}

Keywords: Nanoparticles, Lysosomes, Cathepsin B, Lysosomal sulfatase, Accumulation

\section{Background}

Nano-sized materials are promising tools for new technologies in industrial, pharmaceutical and medical applications. On the other hand, nanoparticles (NPs) may cause adverse cellular events ranging from acute cytotoxicity, induction of inflammation to genotoxic effects [1]. Even if acute adverse cellular effects are not as obvious as, for instance, cell death and inhibition of proliferation, biopersistance and accumulation of NPs may interfere with the physiological function of cells and organs.

The increased incidence of several types of chronic diseases, mainly of the respiratory and cardiovascular system but also neurodegenerative diseases, after long

\footnotetext{
* Correspondence: eleonore.froehlich@medunigraz.at

${ }^{1}$ Center for Medical Research, Medical University of Graz, Graz, Austria

${ }^{2}$ Department of Internal Medicine, Division of Endocrinology and Nuclear

Medicine, Medical University of Graz, Graz, Austria

Full list of author information is available at the end of the article
}

term exposure to particulate matter is mentioned in numerous studies e.g.[2]. Also smaller effects such as impairment of cognitive function have been reported [3]. Mechanisms for the pathogenic action include generation of reactive oxygen species and induction of inflammation [4]. In addition, insufficient degradation of protein aggregates in neurodegenerative diseases (e.g. tau protein in Alzheimer's disease, $\alpha$-synuclein in Parkinson's disease) by lysosomes induced by NPs may represent an additional causative factor.

Biopersistance of NPs has been demonstrated in several studies. After only one injection quantum dots were detectable in liver and spleen for 6 months $[5,6]$, titanium dioxide NPs persisted for 28 days $[7,8]$ and gold NPs were seen after 8 days [9]. When rats were exposed by inhalation to $20 \mathrm{~nm}$ and $250 \mathrm{~nm}$ TiO2 particles persistence, alteration of lung histology and of macrophage function at one year post-exposure were much more pronounced for the small particles [10]. As

\section{() Biomed Central}


NPs are also taken up by non-phagocytic cells, biopersistance may also occur in these cells and lead to impaired cell function.

Long-term effects of NPs are mainly investigated by in-vivo experiments. After repeated inhalative exposure to silver and titanium dioxide NPs, minimal histopathological changes at the portal of entry and alterations in white blood counts were seen [11-13]. Other effects of NPs, like a reduced anti-bacterial defence, were only identified when animals, repeatedly exposed to diesel exhaust particles, were subjected to challenge with listeria pathogens [14].

To minimize the influence of adaption it may be advantageous to look at organelles, where accumulation is most likely. NPs are taken up by passive and active mechanisms. Passive uptake of NPs was seen for titanium dioxide particles by adhesive interaction [15] or by passive diffusion for titanium dioxide and gold particles up to a size of $200 \mathrm{~nm}$ [16]. The passage of NPs through membrane protein channel has been proposed but experimental proof is lacking [17]. Active entry in nonphagocytic cells occurs via various mechanisms of endocytosis, which are enumerated without going into detail. Clathrin-mediated uptake, caveolae, macropinocytosis and clathrin- and caveolae-independent uptake were identified. Typical classifications employ coating proteins, GTPases or the absence of lipid rafts for discrimination of different clathrin- and caveolaeindependent endocytotic mechanisms. According to the type of GTPase Arf6-dependent, Cdc42/Arf1-dependent and RhoA-dependent endocytosis can be discerned. Presence of the coat protein Flotillin is characteristic for Flotillin-dependent endocytosis [18]. Another nomenclature employs the term clathrin-independent carriers/ glycophosphatidylinositol (GPI)-anchored protein enriched compartment (GEEC)-type endocytosis as synonym for Cdc42/Arf1-dependent endocytosis and IL-2R $\beta$-dependent endocytosis for RhoA-dependent endocytosis [19] (Figure 1). The material, which is taken up by endocytosis, is transported by clathrin-coated pits, macropinosomes, caveosomes, glycophosphatidylinositol (GPI)-anchored protein enriched compartments and other sorting endosomes mainly to lysosomes. The non-degradative route of caveolin-dependent uptake may also deliver the content of the caveosome to the endoplasmic reticulum and the Golgi apparatus. Spherical NPs made from iron oxide, polystyrene, gold, cadmium selenide (quantum dots) and titanium dioxide as well as nanodiamonds appear to be stored in lysosomes [20-26]. They can accumulate there because degradation of inorganic NPs in lysosomes is unlikely.

Acute damage of lysosomes may occur through oxidative stress; lysosomal membranes are especially sensitive to reactive oxygen and nitrogen species [27]. For some particles like fullerenes and quantum dots cytotoxicity by lysosome membrane damage has been reported $[28,29]$. For prolonged exposure to NPs organelle damage by accumulation may also occur. Change in lysosome morphology and decrease of lysosomal membrane stability by accumulation of non digested NPs has already been shown for NPs from glass wool by Koehler et al. [30]. The effects of accumulation products on lysosomes have been studied for the physiological accumulation product lipofuscin, the lipid-containing residues of lysosomal digestion. Lipofuscin in lysosomes can cause increases in lysosomal $\mathrm{pH}$ and inhibition of lysosomal enzymes [31]. Garnett and Kallinteri [32] suggested that accumulation of NPs might cause similar symptoms as lysosomal storage diseases. Inherited lysosomal storage diseases are good examples of the importance of lysosomal enzymes for cell function. Deficiency of specific lysosomal enzymes, for instance lysosomal sulfatases arylsulfatase A, B and G, causes lysosomal storage diseases [33]. The impaired autophagic delivery of bulk cytosolic contents to lysosomes finally resulting in accumulation of toxic protein, cellular damage and apoptosis leads to a wide spectrum of symptoms ranging from movement disorders, seizures and dementia to hepatomegaly and splenomegaly, and pulmonary and cardiac problems [34]. Drug-induced lysosomal phospholipidosis and inherited lysosomal storage disorder share analogies regarding clinical symptoms and molecular mechanisms [35]. Although it is not expected that the accumulation of NPs can cause symptoms as severe as those seen in inherited lysosomal storage diseases, such effects should be included in a realistic risk assessment of particle exposure.

For this study we used carboxyl polystyrene particles (CPS) because these particles can be obtained in reproducible quality, in a wide size range and in core-labelled fluorescent form allowing localization and tracking in living cells. In addition, they are not bio-degradable and the effect of intracellular accumulation can be studied. These particles show a size-dependent toxicity [36,37], which allows the comparison of cytotoxic and non cytotoxic particles with the same composition and under the same conditions. Intracellular distribution, lysosomal stability, $\mathrm{pH}$ and enzyme function after short and longer exposures were studied. To avoid dilution of the particles by cell division, cells were growth retarded by serum reduction.

\section{Results}

\section{Characterization of the in-vitro model} Cell culture

Pilot experiments showed that upon cell proliferation the intracellular content of particles decreases rapidly. Therefore, cell proliferation has to be prevented when an effect of particles accumulation is studied. In order to 


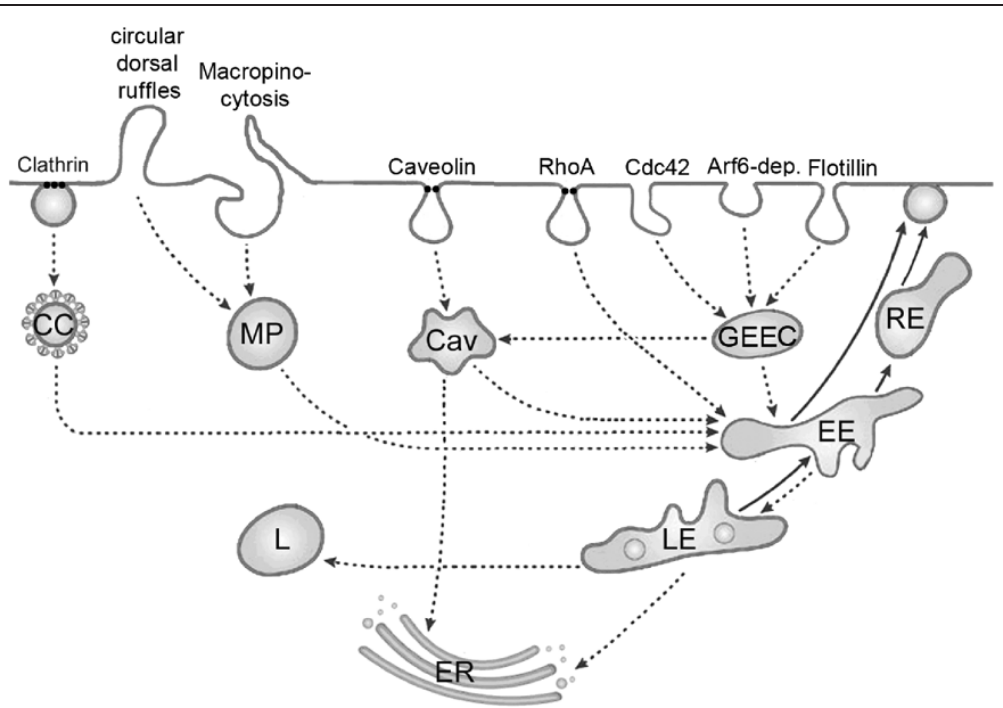

Figure 1 Schematic simplified representation of potential routes for active uptake of in non-phagocytic cells. Mechanisms of endocytosis include clathrin-dependent and clathrin-independent routes. Clathrin-dependent uptake occurs via clathrin-coated pits (CC). Clathrin-independent routes include ingestion by macropinocytosis and circular dorsal ruffles via macropinosomes (MP), caveolae-mediated endocytosis via caveosomes (Cav) and various non-clathrin non-caveolae mediated processes. The later can be subdivided into RhoA/L2 $\beta$ pathway, Arf1/Cdc42, flotillin and Arf6 endocytosis. Whereas RhoA/IL2 $\beta$ receptor uptake involves specific tubulovesicular endosomes, the content of Arf1/Cdc42, flotillin and Arf6 endocytotic vesicles is delivered to glycophosphatidylinositol-anchored protein-enriched compartments (GEEC). Caveosomes may deliver their content to the endoplasmatic reticulum (ER) and to early endosomes (EE). The other routes transport the ingested material via endosomes (EE) and late endocytotic vesicles (LE) to lysosomes (L). Late endocytotic vesicles may also contact the endoplasmic reticulum. Recycling of membranes occurs via recycling endosomes (RE).

produce viable non-proliferating cells, the serum concentration in the medium was decreased. The concentration of serum was chosen according to cell number and viability. Requirements for the exposure conditions were: variation in the cell number $\leq 15 \%$ between day 1 and day 5 and viability of the cells $\geq 85 \%$. At a concentration of $2 \% \mathrm{FBS}$ in the medium these requirements were fulfilled. At 1\% FBS cell number and viability of the cells were lower and at 5\% FBS cell number was too high.

To find out if serum reduction would induce changes, especially in lysosomal genes, gene-expression was analyzed. De-regulated genes were involved in primary metabolic and cellular processes, cell communication, signal transduction and response to stimuli (supplementary information, Additional file 1: Table S1 A, B). A search for de-regulation of lysosomal genes showed no hits. (The complete list of the de-regulated genes is provided as supplementary information, Additional file 2: Table S2).

\section{Carboxyl polystyrene particles (CPS)}

For the interpretation of the experiments potential aggregation of particles and surface charge are important as these parameters are influenced by $\mathrm{pH}$, ionic strength and protein content. To this aim hydrodynamic size and surface charge of the CPS particles were determined in the medium used for testing (Table 1). Compared to the nominal size of the CPS, increases in DMEM + 2\% FBS medium were more pronounced for the small $20 \mathrm{~nm}$ and $40 \mathrm{~nm}$ CPS, where 2-3.35-fold increases in size were noted compared to 1.01-1.7 fold increases in size for the larger $\geq 100 \mathrm{~nm}$ CPS. Surface charge ranged between -11.3 and $-14.7 \mathrm{mV}$ for all particles.

\section{Cellular particle uptake}

The amount of cellular particle uptake was sizedependent and increased from 24h to $48 \mathrm{~h}$ (Table 2). While the number of intracellular particle numbers was highest for $20 \mathrm{~nm}$, the relative rate of ingested particles was lowest. The factor 10 in the size difference between

\begin{tabular}{|c|c|c|c|}
\hline Size $(\mathrm{nm})$ & Size $(\mathrm{nm})$ & C-pot.(mV) & Increase \\
\hline$\overline{\text { CPS (nominal size) }}$ & $\overline{\text { DMEM, } 2 \% \text { FBS }}$ & $\overline{\text { DMEM, } 2 \% \text { FBS }}$ & \\
\hline 20 & 67 & -11.3 & 3,35 \\
\hline 40 & 80 & -14.7 & 2,00 \\
\hline 100 & 170 & -12.1 & 1,70 \\
\hline 200 & 254 & -12.5 & 1,27 \\
\hline 500 & 543 & -11.5 & 1,09 \\
\hline 1000 & 1407 & -11.3 & 1,41 \\
\hline
\end{tabular}


Table 2 Uptake rates of fluorescently labeled carboxyl polystyrene particles (FS) by EAhy926 cells given as number of particles ( $\mathrm{N}$ ) and percentage of applied dose (\%)

\begin{tabular}{|c|c|c|c|c|c|c|}
\hline \multirow[b]{2}{*}{ Size $(\mathrm{nm})$} & \multicolumn{2}{|l|}{$24 \mathrm{~h}$} & \multicolumn{2}{|l|}{$48 \mathrm{~h}$} & \multicolumn{2}{|l|}{$72 \mathrm{~h}$} \\
\hline & $\mathbf{N}$ & $\%$ & $\mathrm{~N}$ & $\%$ & $\mathbf{N}$ & $\%$ \\
\hline 20 & $8.7^{*} 10 \wedge 5$ & 4.6 & $9.5^{*} 10 \wedge 5$ & 8.7 & $9.3^{*} 10 \wedge 5$ & 8.9 \\
\hline 40 & $9.6^{*} 10^{\wedge} 4$ & 4.9 & $1.2^{*} 10 \wedge 5$ & 9.1 & $1.3^{*} 10 \wedge 5$ & 8.6 \\
\hline 100 & $1.6^{*} 10^{\wedge} 4$ & 10.4 & $2.0^{*} 10 \wedge 4$ & 20.6 & $2.2^{*} 10^{\wedge} 4$ & 22.9 \\
\hline 200 & $4.7^{*} 10^{\wedge} 3$ & 17.2 & $5.3^{*} 10 \wedge 3$ & 41.9 & $5.3^{*} 10^{\wedge} 3$ & 40.9 \\
\hline 500 & $3.8^{*} 10 \wedge 2$ & 28.4 & $5.8^{*} 10 \wedge 2$ & 67.9 & $5.4^{*} 10^{\wedge} 2$ & 70 \\
\hline
\end{tabular}

$20 \mathrm{~nm}$ and $200 \mathrm{~nm}$ CPS resulted in about 20 times more particles, which were taken up by the cells. Normalized to the applied dose, however, only about $5 \%$ of the 20 $\mathrm{nm}$ CPS compared to $17 \%$ of the $200 \mathrm{~nm}$ ones were taken up by cells after $24 \mathrm{~h}$ of exposure.

\section{Cell damage and oxidative stress upon particle exposure}

Cells exposed to CPS for different times showed a dosedependent decrease in viability for the $20 \mathrm{~nm}$ CPS while no decrease of viability was seen in the case of $200 \mathrm{~nm}$ CPS. The dose-dependent decrease in viability was steeper when cells were exposed for 48-120h with the 20 $\mathrm{nm}$ CPS (Figure 2). After 120h of exposure viability had decreased to $70 \pm 5 \%$ compared to $94 \pm 3 \%$ after $24 \mathrm{~h}$. At $50 \mu \mathrm{g} / \mathrm{ml} 20 \mathrm{~nm}$ CPS upon $72 \mathrm{~h}$ of exposure viability was only slightly decreased $(92 \pm 12 \%)$ compared to untreated cells. No decrease in cell viability at any time point was seen up to $100 \mu \mathrm{g} / \mathrm{ml} 200 \mathrm{~nm}$ CPS. As expected for a fluorescence core-labelled particle no differences in cytotoxicity were observed between CPS and the labeled counterparts (FluoSpheres ${ }^{\circledR}$, data not shown). For the

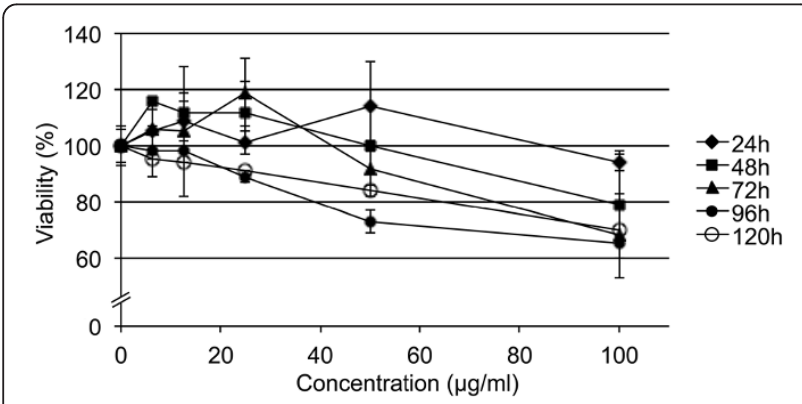

Figure 2 Dose-dependent change in viability assessed by formazan bioreduction in EAhy 926 cells exposed to $20 \mathrm{~nm}$ CPS in DMEM + 2\%FBS for different times. Decreases are related to the respective not CPS-exposed cultures as 100\% at 24h-48h-72h-96h and $120 \mathrm{~h}$ of exposure. At doses $(10,20,40 \mu \mathrm{g} / \mathrm{ml})$ and exposure times (72h) used for the studies on lysosome metabolism, no significant decrease in viability is seen $(p<0.05)$. exposures we chose concentrations of 10,20 and $40 \mu \mathrm{g} /$ $\mathrm{ml}$ for all CPS to exclude a cytotoxic effect.

To find out if at these concentrations of CPS, oxidative stress was induced, the oxidation of the non-fluorescent dichlorodihydrofluorescein to fluorescent dichlorofluorescein was exploited. After $24 \mathrm{~h}$ of incubation with 50 $\mu \mathrm{g} / \mathrm{ml} 20 \mathrm{~nm}$ CPS the fluorescence increased to $135.7 \pm 44 \%$ of that of the untreated controls compared to $363 \pm 48 \%$ in the positive control $\left(200 \mu \mathrm{M} \mathrm{H}_{2} \mathrm{O}_{2}\right)$. Fluorescence after exposure to $50 \mu \mathrm{g} / \mathrm{ml} 200 \mathrm{~nm}$ CPS reached $116 \pm 1.4 \%$ of the untreated controls (data not shown). The increases caused by the CPS did not reach the level of significance.

\section{Localization in lysosomes}

To find out if CPS at a single exposure of $25 \mu \mathrm{g} / \mathrm{ml} \mathrm{ac-}$ cumulate in lysosomes co-localization of fluorescent CPS (FluoSpheres ${ }^{\circledR}$ ) and lysosomes identified by activity for cathepsin $\mathrm{B}$ and $\mathrm{pH}$ sensitive dye was performed. The majority of organelles stained with both LysoSensor and cathepsin B substrate but small organelles in the cellular periphery reacted only with LysoSensor (Additional file 3: Figure S3). Pictures taken immediately after removal of the particles after $4 \mathrm{~h}$ of incubation and after $24 \mathrm{~h}$ of post-incubation in medium showed that the 20 $\mathrm{nm}$ and $40 \mathrm{~nm}$ particles co-localized with lysosome markers whereas many $200 \mathrm{~nm}$ and $500 \mathrm{~nm}$ FS were still located at the cell periphery (Figure 3a, co-localization with LysoSensor shown). After 24h particles of all sizes were seen inside the cells and only differences in the colocalization rates between the smallest particles and 500 $\mathrm{nm}$ particles were obvious (Figure $3 \mathrm{~b}$ ). Quantification of the co-localization on a pixel basis using Metamorph software (Figure 3c) also showed significant differences between the co-localization of small $(<100 \mathrm{~nm})$ and larger particles after $4 \mathrm{~h}$, whereas after $24 \mathrm{~h}$ only the colocalization rates between $20 \mathrm{~nm}$ and $40 \mathrm{~nm}$ versus 500 $\mathrm{nm}$ particles were found to be significantly different. There were no significant differences in the colocalization rate of the particles between the use of cathepsin $\mathrm{B}$ and of $\mathrm{pH}$ sensitive dye as lysosome marker.

\section{Lysosome function \& integrity}

To assess lysosomal morphology and function, dyerelease induced by loss of lysosome membrane integrity, measurements of $\mathrm{pH}$ by fluorescent dye, a screening assay for lysosomal perturbation/dilation of the endosomal-lysosomal system in drug development and enzymatic assays for lysosome activity, were used. Chloroquine, a drug known to increase intralysosomal $\mathrm{pH}$ and to inhibit the activities of arylsulfatase $\mathrm{B}$ and cathepsin B activity [38,39], was used as positive control. 

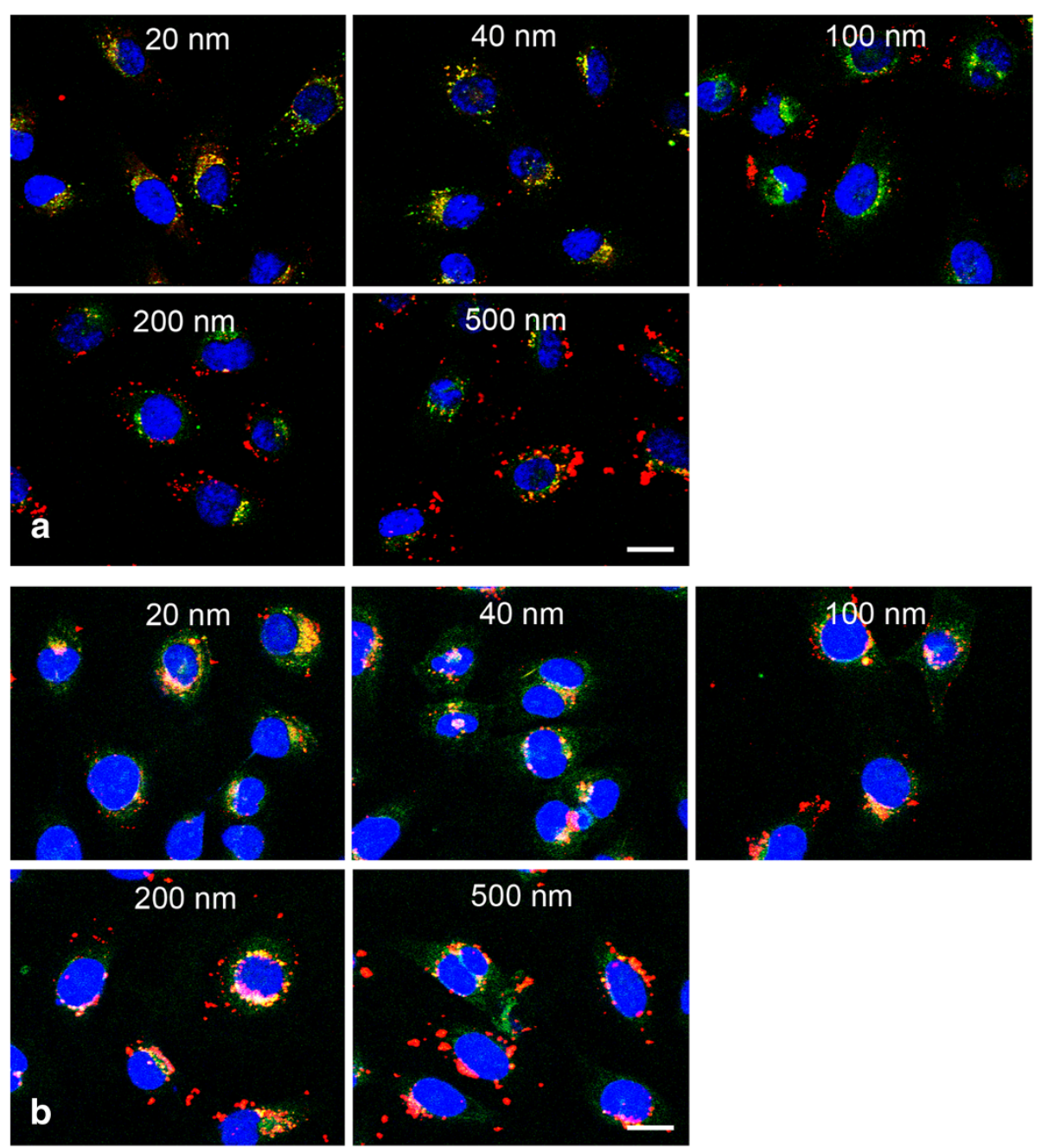

$4 \mathrm{~h}$
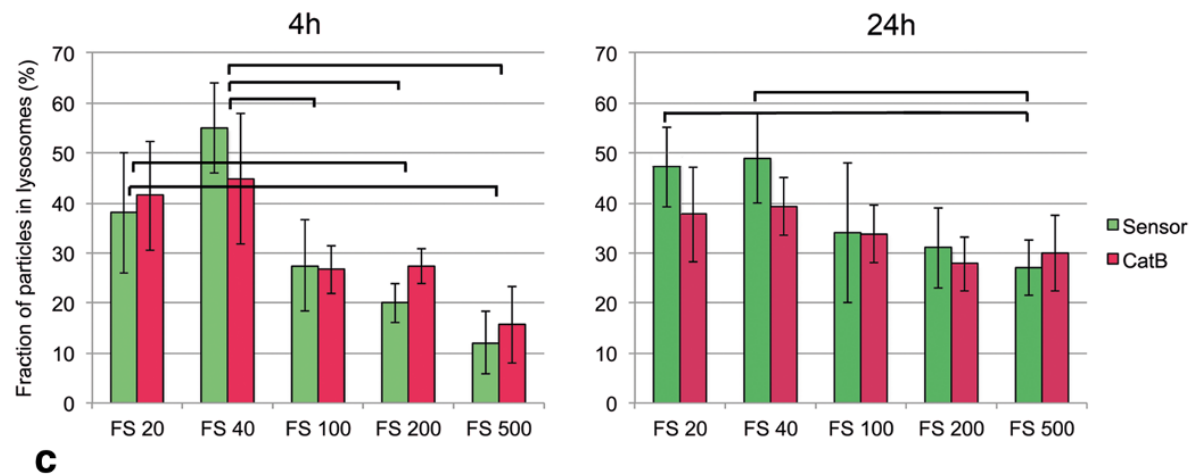

Figure 3 Co-localization of fluorescently labeled CPS (FluoSpheres, $25 \mu \mathrm{g} / \mathrm{ml}$ in DMEM $+2 \% \mathrm{FBS}$ ) and lysosomes identified by LysoSensor and cathepsin B activity by CV-(RR) 2 substrate in EAhy 926 cells after $4 \mathrm{~h}$ of exposure (a) and $24 \mathrm{~h}$ (b) after particles were removed from the incubation medium. a: Co-labelling of FluoSpheres (FS red) with LysoSensor as marker for lysosomes (green). Scale bar: 10 $\mu \mathrm{m}$. After 4h co-localization (yellow) is seen for $20 \mathrm{~nm}$ and $40 \mathrm{~nm}$ FS while $100 \mathrm{~nm}, 200 \mathrm{~nm}$ and $500 \mathrm{~nm}$ FS are seen predominantly at the cell periphery. b: After 24h more $100 \mathrm{~nm}-500 \mathrm{~nm}$ FS co-localize with lysosomes and only $500 \mathrm{~nm}$ FS were seen at the cell periphery. c: quantification of the co-localization by Metamorph ${ }^{\circledR}$ software: the pH-dependent dye LysoSensor (Sensor, green) and enzymatic activity for the lysosomal enzyme cathepsin B (CatB, red) are used as markers for lysosomes. Co-localization rates of FS with LysoSensor were slightly higher than those with CatB substrate. After 4h significant differences in the co-localization rates were seen in the combinations: $20 \mathrm{~nm}$ FS versus $200 \mathrm{~nm}$ and 500 $\mathrm{nm} \mathrm{FS}$ and $40 \mathrm{~nm}$ FS versus 100nm, $200 \mathrm{~nm}$ and $500 \mathrm{~nm}$ FS. After 24h only the differences between $20 \mathrm{~nm}$ and $40 \mathrm{~nm}$ FS on the one hand and $500 \mathrm{~nm}$ FS were significant. Particles with significant differences in the co-localization rates $(p<0.05)$ are linked by brackets. 


\section{Changes in lysosomal membrane integrity, morphology and $\mathrm{pH}$}

Strong damage of lysosomal membranes leads to release of the fluorescent dye Lucifer yellow, whereas minor damage can lead to changes in the lysosomal $\mathrm{pH}$ identified by decrease in the staining with the indicator dye LysoSensor. As it may be difficult to detect small increases in lysosomal $\mathrm{pH}$ based on fluorescence, the switch of the Acridine Orange fluorescence from red in healthy lysosomes to green in lysosomes with increased $\mathrm{pH}$ was used in addition. Finally, also an assay used in the screening for lysomotropic effects (lysosomal perturbation assay) was used. This assay is based on the increase in the green fluorescence of NBZ-PZ relative to the red fluorescence of propidium iodide as indication for dilatation of the endosomallysosomal system. The effect of $20 \mu \mathrm{g} / \mathrm{ml}$ and $40 \mu \mathrm{g} / \mathrm{ml}$ CPS was investigated.

In the incubations with Lucifer Yellow the positive control (100 $\mu \mathrm{M}$ chloroquine) after $24 \mathrm{~h}$ led to leakage of the dye into the cytoplasm resulting in a diffuse cytoplasmic staining instead of the punctate pattern in normal cells (Additional file 3: Figure S1, $20 \mu \mathrm{g} / \mathrm{ml}$ shown).
The staining of cells exposed to $20 \mathrm{~nm}$ and $200 \mathrm{~nm}$ CPS for 24h was not different from not exposed cells. After $72 \mathrm{~h}$ the signal was too low for evaluation.

Also the staining with LysoSensor did not show differences between $20 \mathrm{~nm}$ CPS, $200 \mathrm{~nm}$ CPS exposed cells $(20 \mu \mathrm{g} / \mathrm{ml}$ and $40 \mu \mathrm{g} / \mathrm{ml})$ and not exposed cells for $24 \mathrm{~h}$ and $72 \mathrm{~h}$ (data not shown).

Morphology of acridine orange stained cells exposed to $25 \mu \mathrm{M}$ chloroquine showed enlarged lysosomes with marked increase in green fluorescence as indication for lysosomal swelling (Figure 4b). Cells exposed to $20 \mu \mathrm{g} /$ $\mathrm{ml}$ and $40 \mu \mathrm{g} / \mathrm{ml} 20 \mathrm{~nm}$ and $200 \mathrm{~nm}$ CPS as well as not particle exposed cells showed occasionally lysosomes with increased green staining but no enlargement of the organelles (Figure 4a, c, d, $20 \mu \mathrm{g} / \mathrm{ml}$ shown). To quantify these findings relative fluorescence in the red compared to the green channel was determined by fluorometry and a significant decrease in this ratio was seen for the positive control chloroquine $(70.3 \pm 2.2 \%)$. Neither in cells exposed to $20 \mu \mathrm{g} / \mathrm{ml} 20 \mathrm{~nm}$ CPS nor to those exposed to $20 \mu \mathrm{g} / \mathrm{ml} 200 \mathrm{~nm}$ CPS this ratio was significantly different from not exposed cells (91.37 $\pm 11.7 \%$ and $92.87 \pm 13.2 \%$, respectively).
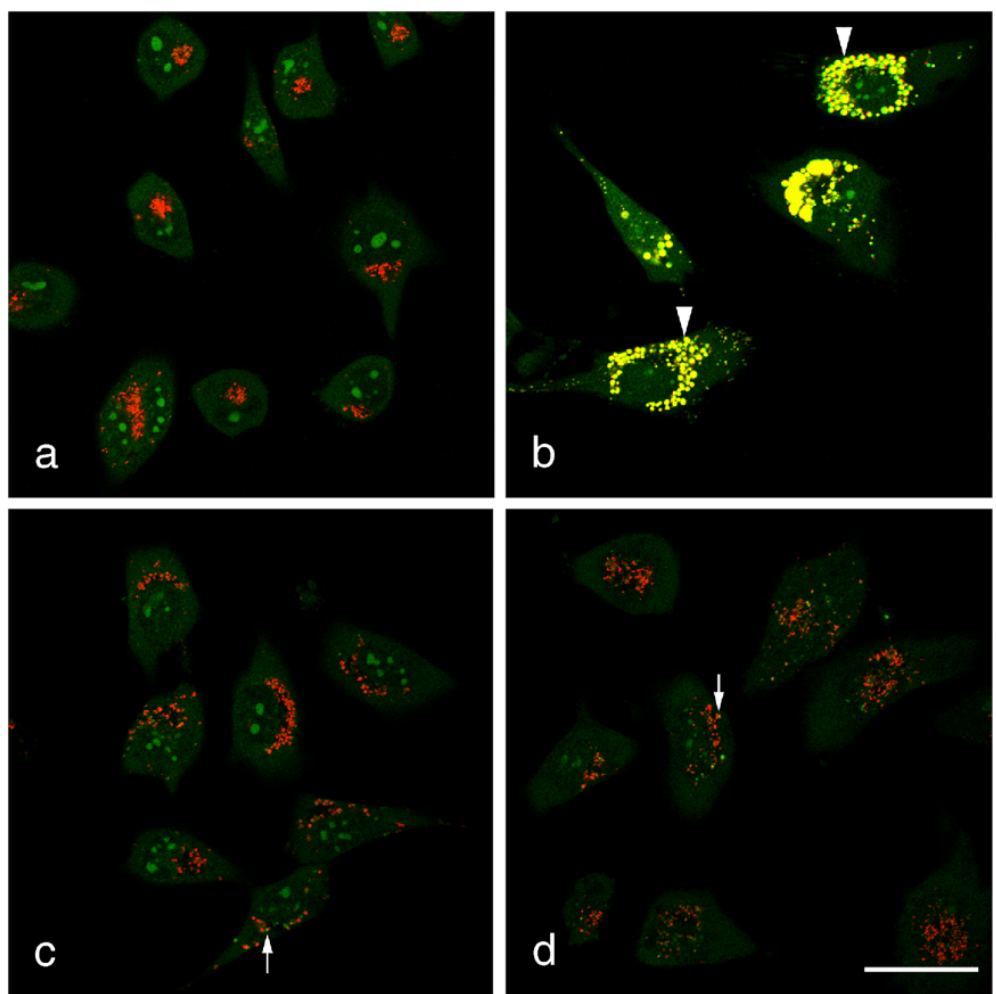

Figure 4 EAhy 926 cells stained with acridine orange after treatment with DMEM $+2 \% \mathrm{FBS}(\mathrm{a}), 25 \mu \mathrm{M}$ chloroquine (positive control, b), $20 \mu \mathrm{g} / \mathrm{ml} 20 \mathrm{~nm}$ CPS (c) and $20 \mu \mathrm{g} / \mathrm{ml} 200 \mathrm{~nm}$ CPS (d). DNA and RNA are stained green by acridine orange; healthy lysosomes stain only red. Upon exposure to chloroquine (b) lysosomes increase in size and stain in green and red (yellow, arrow head) indicating increase in lysosomal pH and lysosomal swelling. Cells treated with CPS (c, d) show red lysosomes and only rarely double-stained yellow lysosomes (arrows). Scale bar: $10 \mu \mathrm{m}$. 

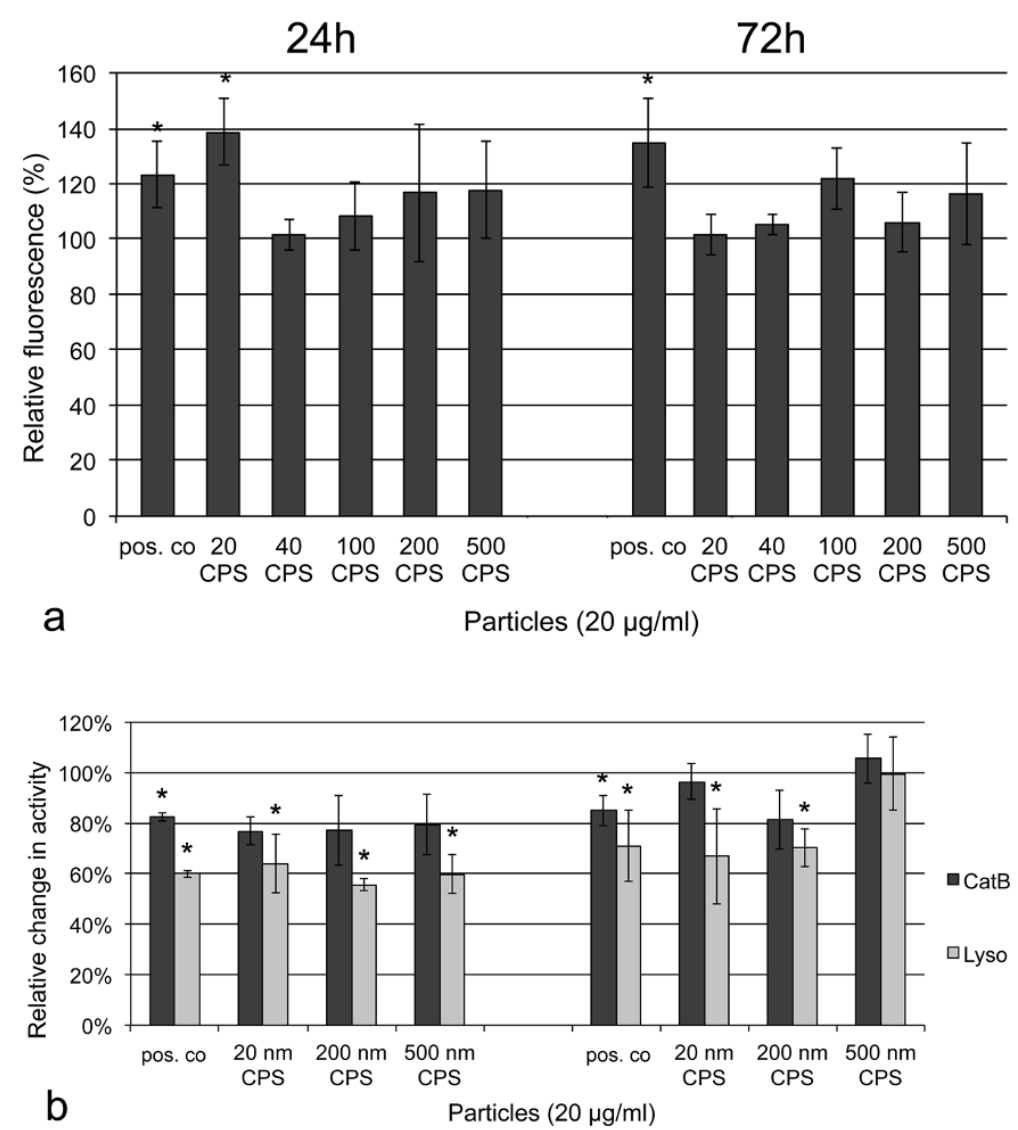

Figure 5 Enlargement of the endosomal-lysosomal system and changes in lysosomal enzyme activities in EAhy926 cells after $24 \mathrm{~h}$ and $72 \mathrm{~h}$ of exposure to $20 \mu \mathrm{g} / \mathrm{ml}$ CPS of different sizes in DMEM + 2\%FBS. $25 \mu \mathrm{M}$ chloroquine was used as positive control (pos. co). a: Lysosomal/cytotoxicity assay, where an increase in the green signal is interpreted as perturbation in lysosome function. The signal is normalized to that of un-treated cells as 100\%. Significant effects (asterisk) are seen only after incubation for 24h with $20 \mathrm{~nm}$ CPS. b: Changes in the reactivity with CV-(RR) $)_{2}$ for cathepsin B (CatB) and with substrate for lysosomal sulfatases (Lyso). Arbitrary fluorescence data are normalized to the amount of LAMP-1 staining and the signal of un-treated cells is set as 100\%. In general, decreases in lysosomal activities were more pronounced after $24 \mathrm{~h}$ of exposure than after $72 \mathrm{~h}$ of exposure and the effect on lysosomal sulfatases was higher than that on cathepsin B. After $24 \mathrm{~h}$ of exposure, significant decreases in the activity of lysosomal sulfatase were seen for all particles. After $72 \mathrm{~h}$, such significant decreases were only seen upon exposure to $20 \mathrm{~nm}$ CPS and $200 \mathrm{~nm}$ CPS. Significant changes are marked by asterisks.

In the lysosomal perturbation assay, a significant increase in the green fluorescence was only seen for the exposure to $20 \mu \mathrm{g} / \mathrm{ml}$ and $40 \mu \mathrm{g} / \mathrm{ml} 20 \mathrm{~nm}$ CPS for $24 \mathrm{~h}$ (Figure $5 \mathrm{a}, 20 \mu \mathrm{g} / \mathrm{ml}$ shown) and the positive control ( $25 \mu \mathrm{M}$ chloroquine) at both time points. An increase in the amount of endosomal-lysosomal membranes was also seen when cells exposed for $24 \mathrm{~h}$ to both concentrations of CPS were stained with anti-LAMP-1 antibody as marker for late endosomes and lysosomes. This increase to $135 \pm 22 \%$ of the controls was not significant but was seen for all CPS-treated samples and at both concentrations of CPS (data not shown). After $72 \mathrm{~h}$ of exposure to all particles, fluorescence in the green and red were similar to those of the untreated controls in the lysosomal perturbation assay (Figure 5a). Similarly, also the increase in the anti-LAMP-1 staining of CPS exposed cells was no more seen $(104 \pm 6 \%$ of the controls).

\section{Changes in enzyme activity}

The assessment of cathepsin B activity in homogenates did not produce reliable data and the in-situ detection was used instead. The in-situ detection of cathepsin B and lysosomal sulfatase activity is based on the diffusion of substrates into the lysosomes, where they are metabolized and result in a fluorescent product. The fluorescence was normalized to the intensity of the staining with anti-LAMP-1 antibody, as marker for the endosomal-lysosomal system since slight increases in LAMP-1 staining were seen upon exposure to CPS (see section lysosomal perturbation).

The decrease in lysosomal sulfatase activity was strongest after $24 \mathrm{~h}$ of exposure to $20 \mu \mathrm{g} / \mathrm{ml}$ CPS (Figure $5 \mathrm{~b}$ ). $20 \mathrm{~nm}, 200 \mathrm{~nm}$ and $500 \mathrm{~nm}$ CPS decreased lysosomal sulfatase activity significantly; the decrease was most pronounced for $20 \mathrm{~nm}$ CPS. After $72 \mathrm{~h}$ of exposure still 
significant decreases in lysosomal sulfatase activity were seen after exposure to $20 \mathrm{~nm}$ CPS and $200 \mathrm{~nm}$ CPS but not to $500 \mathrm{~nm}$. Decrease of cathepsin B activity was not significant for these particles at both time points.

\section{Discussion}

In this study the intracellular distribution of CPS, as models for non- biodegradable NPs, and their effect on lysosomes of the endothelial cell line EAhy926 was studied after $24 \mathrm{~h}$ and $72 \mathrm{~h}$ of exposure. These particles also served to identify assays, which could be used for the assessment of lysosomal effects of other NPs. $20 \mu \mathrm{g} / \mathrm{ml}$ and $40 \mu \mathrm{g} / \mathrm{ml}$ reacted similarly. In addition to dilatation of the endosomal-lysosomal system (lysosome/cytotoxicity dual staining kit), decreases in the activities of lysosomal enzymes (cathepsin B, lysosomal sulfatase) were seen. Overall, the observed effects were small and more pronounced at $24 \mathrm{~h}$ than at $72 \mathrm{~h}$ of incubation suggesting that prolonged contact does not cause lysosomal damage.

In this study the intracellular localization and effects on lysosomes of CPS were studied at $50 \mu \mathrm{g} / \mathrm{ml}$ as highest concentration in EAhy926 cells. These concentrations appear realistic for chronic effects upon repeated intravenous exposure and EAhy926 cells as endothelial cell lines are relevant target cells. In the cytostatic Abraxane ${ }^{\circledR}$ the drug load accounts for $10 \%$ of the total nanoparticle mass. Maximum serum concentrations for paclitaxel are $23 \mu \mathrm{g} / \mathrm{ml}$ [40], corresponding to nanoparticle concentrations of $230 \mu \mathrm{g} / \mathrm{ml}$. Imaging agents based on gadolinium chelates may reach blood concentrations of $1 \mathrm{mg} / \mathrm{ml}$ (http://www.berlex.com/html/products/pi/ Magnevist_PI.pdf), but blood levels for iron oxide NPs in Resovist $^{\circledR}$ range around $100 \mu \mathrm{g} / \mathrm{ml}$ [41]. The given concentrations are peak levels and not typical for chronic exposure. On the other hand, cellular accumulation has been shown in animal experiments [5-9,42] and may maintain intracellular levels of NPs at a lower level over a prolonged period of time.

For the studies on lysosomes, we used serum-reduced cells to slow down proliferation and, thereby, prevent dilution of the intracellular nanoparticle concentration by cell division. Exposure to 0-1\% FBS has been reported to decrease cell viability and induce apoptosis and necrosis in different cell lines [43-45]. In contrast to synthesis of RNA and DNA, protein synthesis was largely unaffected in L929 fibroblasts by serum deprivation but reduced in 3T3 fibroblasts [46,47]. To find out if serum deprivation displayed major effects on the EAhy926 cells used in this study, whole genome analysis was performed. As expected genes involved in pathways such as cell cycle, proliferation and apoptosis were changed but no effects on lysosomal genes were identified. The reduction of the serum content from $10 \%$ to $2 \%$, therefore, appears to be suitable for the study of lysosomes.

As prerequisite for lysosomal accumulation, intracellular localization of fluorescent CPS was studied. Already after 4h of exposure, $20 \mathrm{~nm}$ CPS showed a high rate of colocalization to endosomes and lysosomes. Consistent with studies by Lai et al. [48] the co-localization rate of $40 \mathrm{~nm}$ CPS was higher than that of $20 \mathrm{~nm}$ CPS. Co-localization of $>40 \mathrm{~nm}$ CPS with lysosomes in our study increased with time and after 24h CPS also $500 \mathrm{~nm}$ CPS were localized in lysosomes. Although different uptake mechanisms have been reported, most NPs, like for instance mesoporous silica particles, silicon dioxide particles, gold particles and quantum dots predominantly were localized in lysosomes [49-52]. Size compared to surface charge appears to play only a minor role for lysosomal localization [53]. Nanoceria particles with positive and negative surface charge localized outside and inside lysosomes, respectively. Cytotoxicity data after $24 \mathrm{~h}$ of exposure showed a much higher effect for lysosomal localization and the authors hypothesized that lysosomal localization is correlated to cytotoxicity on NPs in tumor cells. The authors do, however, not indicate if lysosomal changes are implicated in this tumor selective damage.

The occurrence of lysosomal damage without cell destruction is a well-known drug-induced lysosomal storage disorder termed lysosomal phospholipidosis. Several organic amines, namely chloroquine, amiodarone, perhexiline, aminoglycosides and chlorphentermine accumulate in the acidic environment of endosomes and lysosomes and cause the accumulation of membraneous material [54]. As positively charged molecules, they cause swelling and disruption of the lysosomes with subsequent cell death at high concentrations. Screening assays like the lysosomal/cytotoxicity dual staining kit or the Lyso-ID Red detection kit, both based on the combination of a membrane permeable dye with a marker for cell death or cell number, have been developed to identify drug-induced dilatation of the endosomallysosomal system due accumulation of lysosomal membranes [55,56]. Using the lysosomal/cytotoxicity dual staining kit, perturbation of lysosome function after exposure of cells to $20 \mathrm{~nm}$ CPS for $24 \mathrm{~h}$ was identified. The interference with lysosome function of the $20 \mathrm{~nm}$ particles and absence of this effect of the $40 \mathrm{~nm}$ CPS may be caused by differences in the intracellular concentration of the particles that was about 8 times higher for $20 \mathrm{~nm}$ CPS than for $40 \mathrm{~nm}$ CPS. It is, therefore, likely that similar alterations also occur when the other CPS reach such high intracellular particle concentration. As CPS are not positively charged they are unlikely to disrupt lysosomes by neutralization of the acidic environment. Generation of oxidative stress, which has been demonstrated for fullerenes and for quantum dots [28,29] may also 
damage lysosomes. The size of quantum dots and fullerenes is roughly in the same order of magnitude as that of the $20 \mathrm{~nm}$ CPS, but it is not likely that CPS act mainly by generation of oxygen species. In the concentration range, where lysosomal perturbation by $20 \mathrm{~nm}$ CPS was recorded in this paper $(20 \mu \mathrm{g} / \mathrm{ml}$ and $40 \mu \mathrm{g} / \mathrm{ml})$, no significant increase in intracellular oxygen radicals was recorded. The lack of generation of oxygen radicals by CPS is consistent with other data [37,57]. Although no dramatic damage of lysosomal morphology was detected, we identified changes in enzymatic activities, especially of lysosomal sulfatase, upon exposure to CPS for $24 \mathrm{~h}$. These alterations were less pronounced at $72 \mathrm{~h}$ of exposure. A more prominent decrease in enzyme activity at short incubation times than upon longer exposures is consistent with reported decreases in cathepsin B upon short exposure of macrophages to quartz D12 and to polystyrene microparticles [58,59]. Decreases in lysosomal sulfatase activities in this study were always greater than those in cathepsin B activity. This appears to be due to the specificity of the substrate used for the assessment. The substrate SulfGreen is metabolized by all lysosomal sulfatases (MarkerGene LysoLife product information: http://www. markergene.com/product_sheets/pis1377.pdf), whereas the specificity of the cathepsin B substrate for this protease is higher. Provided that CPS acted on all lysosomal enzymes in a similar manner, changes in SulfGreen fluorescence are expected to be greater than those in $\mathrm{CV}-(\mathrm{RR})_{2}$ (cathepsin B substrate) fluorescence.

In contrast to what was expected, damage by longer exposure to CPS was not higher than after shorter exposure. Polystyrene particles have a high potential for binding of proteins and form larger aggregates when in contact with protein-containing solutions [60,61]. It is, therefore, likely that the fraction of primary and potentially toxic particles rapidly declines inside the cell.

\section{Conclusions}

For the CPS investigated in this study only little interference with lysosomal function was seen. Changes were more prominent upon short than upon longer exposure. It may be suspected that by aggregation inside lysosomes the reactivity of CPS is decreased and toxicity reduced. The panel of lysosomal assays, which was validated for CPS in this study, can be used as a tool to identify the action of other types of NPs on lysosomes.

\section{Methods}

\section{Particles}

Carboxyl polystyrene (CPS) latex beads (20, 40, 100, 200, $500 \mathrm{~nm}$ ), and the respective fluorescently labelled carboxyl polystyrene latex beads (FluoSpheres ${ }^{\circledR}$ ) were obtained from Invitrogen. The fluorescently labelled particles contain dyes integrated in the core, which has the advantage that fluorescent and non fluorescent particles have the same surface properties. CPS suspensions were put into an Elmasonic S40 water bath (ultrasonic frequency: $37 \mathrm{kHz}$, Elma, Singen) for 20 min prior to cell exposures and physicochemical characterization. To identify potential leakage of the dye from the FluoSpheres ${ }^{\circledR}$ after exposure for $24 \mathrm{~h}-72 \mathrm{~h}$ to cells at $37^{\circ} \mathrm{C}$ the supernatant of the cellular exposures was assessed for fluorescence. These measurements were performed only for the $500 \mathrm{~nm}$ spheres firstly because they contain the highest amount of fluorochrome and secondly because, according to the producer, it is not recommended to clean polystyrene spheres smaller than $300 \mathrm{~nm}$ by centrifugation. Supernatant containing the $500 \mathrm{~nm}$ FluoSpheres ${ }^{\circledR}$ were centrifuged at $20,000 \mathrm{xg}$ for $20 \mathrm{~min}$ in a Jouan $25 \mathrm{KRi}$ centrifuge and fluorescence measured in a fluorescence plate reader (FLUOstar Optima, BMG Labortechnik) at $584 \mathrm{~nm} / 612 \mathrm{~nm}$. The fluorescence of the supernatant was 5 times higher than medium alone, this signal corresponds to $0.05 \%$ of the fluorescence of the stem solution. As the fluorochromes in the particles are subjected to quenching, whereas the leached fluorochromes are not, the real amount of leached dye is expected to be much lower.

\section{Physicochemical characterization of particles}

Physicochemical characterization of the particles was performed by dynamic light scattering using a Malvern Zetasizer 3000 HS. Particles were diluted with respective medium to $200 \mu \mathrm{g} / \mathrm{ml}$ and sonicated. After equilibration of the sample solution to $25^{\circ} \mathrm{C}$, size and zeta potential were measured at $633 \mathrm{~nm}$ and a detection angle of $90^{\circ}$. NNLS software was used for sample analysis.

\section{Cell culture}

The human endothelial cell line EAhy926 (kind gift from Dr. C. J. Edgell) was cultured in DMEM, 10\% fetal bovine serum (FBS), $2 \mathrm{mM}$ L-glutamine and 1\% penicillin/ streptomycin. Cell numbers were determined by cell counting and analyser system (CASY ${ }^{\circledR} \mathrm{TT}$, Innovatis). The cells were exposed to particles in DMEM $+2 \mathrm{mM}$ L-glutamine for acute cytotoxicity studies and in DMEM, 2\% fetal bovine serum (FBS), $2 \mathrm{mM} \mathrm{L-}$ glutamine for assessment of lysosome function. All cells were cultured at $37^{\circ} \mathrm{C}$ in a humid $95 \%$ air/5\% CO2 atmosphere. Cells were pre-cultured 24h in DMEM $+10 \%$ FBS prior to the experiment. Subsequently, medium was removed and cells exposed to the particles suspended in DMEM + 2\% FBS were cultured for up to $120 \mathrm{~h}$.

\section{RNA isolation}

Total RNA was isolated using RNeasy Mini kit (Qiagen, Stanford, CA, USA) according to the manufacturer's 
recommendations. The integrity of each RNA sample was evaluated using an Agilent 2100 Bioanalyzer (Agilent, Foster City, CA) and only RNAs with an RNA integrity number (RIN) above 9.5 were used for hybridizations.

\section{Hybridization of microarrays}

100 ng of total RNA for each sample were processed using the Affymetrix GeneChip Whole Transcript (WT) Sense Target Labeling Assay according to the manufacturer's instructions (Affymetrix). Double stranded cDNA was synthesized using a random hexamers tagged with a T7 promoter sequence. Using in vitro transcription, cRNA was generated from the double-stranded cDNA template using the Whole Transcript cDNA Synthesis and Amplification Kit (Affymetrix). cDNA was regenerated using a reverse transcription reaction randomly primed with a mix containing dUTP. After hydrolysis of the cRNA with RNase $\mathrm{H}$, the sense strand of cDNA was purified using the Affymetrix sample cleanup module, fragmented by incubation with UDG (uracil DNA glycosylase) and APE 1 (apurinic/apyrimidic endonuclease 1), and terminally biotin-labeled with terminal deoxynucleotidyl transferase using the WT Terminal Labeling Kit (Affymetrix), following the manufacturer's instructions. Biotinylated sense strands were fragmented and hybridized to Affymetrix Human GeneChip 1.0 ST arrays (Affymetrix) using the Hybridization Control and Hybridization Wash and Stain kits (Affymetrix). The hybridization cocktail was incubated overnight at $45^{\circ} \mathrm{C}$ while rotating in a hybridization oven. After $16 \mathrm{~h}$ of hybridization, arrays were washed and stained in an Affymetrix GeneChip fluidics station 450, according to the Affymetrix-recommended protocol. Arrays were scanned on an Affymetrix GeneChip scanner.

\section{Quantification of particle uptake}

After $24 \mathrm{~h}, 48 \mathrm{~h}$ and $72 \mathrm{~h}$ the incubation medium was removed, cells were washed three times with medium and removed from the plastic support by trypsin treatment (5 min with $0.25 \%$ trypsin/EDTA at $37^{\circ} \mathrm{C}$ ). The action of trypsin was stopped with medium. One aliquot of the cell suspension was used for cell counting by CASY and another to measure fluorescence in a fluorescence plate reader (FLUOstar Optima, BMG Labortechnik) at 584 $\mathrm{nm} / 612 \mathrm{~nm}$.

To indicate particle uptake per cell the particle numbers in the stem solution used for the incubations were calculated according to the formula given by the producer (probes.invitrogen.com/media/pis/mp05000.pdf). The fluorescence signals of the stem solutions were measured by serial dilution. Cell suspensions instead of medium alone were used for the dilution to account for autofluorescence or quenching effects caused by the cells.

\section{Formazan bioreduction by MTS}

CellTiter $96^{\circledR}$ AQueous Non-Radioactive Cell Proliferation Assay (Promega) was used according to the manufacturer's instructions. In short, $20 \mu \mathrm{l}$ of the combined MTS/PMS solution was added to $100 \mu \mathrm{l}$ of each well. Plates were incubated for 2 hours at $37^{\circ} \mathrm{C}$ in the cell incubator. Absorbance was read at $490 \mathrm{~nm}$ on a plate reader (SPECTRA MAX plus 384, Molecular Devices).

\section{Evaluation of oxidative stress by oxidation of dichlorodihydrofluorescein}

Cells were grown for $24 \mathrm{~h}$ in cell culture plates and loaded with $10 \mu \mathrm{M}$ 2,7-dichlorodihydrofluorescein diacetate (Invitrogen) in medium for $30 \mathrm{~min}$ at $37^{\circ} \mathrm{C}$. Subsequently, cells were rinsed and cultured for $24 \mathrm{~h}$ with $0-50$ $\mu \mathrm{g} / \mathrm{ml} \mathrm{CPS} \mathrm{or} 200 \mu \mathrm{M} \mathrm{H}_{2} \mathrm{O}_{2}$ as positive control. Fluorescence was read with $485 \mathrm{~nm}$ excitation and $520 \mathrm{~nm}$ emisssion at a FLUOstar Optima (BMG Labortechnik).

\section{Co-localization studies with lysosomes}

For co-localization studies of particles and lysosomes, cells were loaded with 20, 40, 100, $200 \mathrm{~nm}$ and $500 \mathrm{~nm}$ FluoSpheres $(25 \mu \mathrm{g} / \mathrm{ml})$ for $4 \mathrm{~h}$. Subsequently, medium was replaced by fresh medium without particles and cells were cultured for a further $24 \mathrm{~h}$. Thereafter, cells were washed with $\mathrm{PBS}$ and stained for either $\mathrm{pH}$ (LysoSensor $^{\mathrm{Tw}}$ Green DND-189) or cathepsin B activity $\left(\mathrm{CV}-(\mathrm{RR})_{2}\right)$, according to the protocol given below. Nuclei were stained by incubation with Hoechst 33342 $(1 \mu \mathrm{g} / \mathrm{ml})$ for $15 \mathrm{~min}$ at RT. Images were taken with a LSM510 Meta confocal laser scanning microscope (Zeiss) with 405/BP420-480 for the blue channel, 488/ BP 505-550 for the green channel (LysoSensor ${ }^{\text {rum }}$, YG FluoSpheres ${ }^{\circledR}$ ) and 543/LP 560 for the red channel $\left(\mathrm{CV}-(\mathrm{RR})_{2}\right.$, red FluoSpheres $\left.{ }^{\circledR}\right)$. The degree of colocalization was analysed in LSM images from YG FluoSpheres ${ }^{\circledR}$ and Ac-RR-AFC cathepsin substrate as well as from red FluoSpheres ${ }^{\circledR}$ and LysoSensor incubations. For analysis the COLOCAL plugin of Metamorph $^{\circledR} 5.0$ software (Visitron Systems) was used. Images were taken in the multitrack mode and images of the two channels were exported as .jgp files. Settings to suppress crosstalk between the channels had to be set for each particle separately because, as indicated by the producer, fluorescence intensity of the larger FluoSpheres ${ }^{\circledR}$, due to higher fluorochrome content per particle, is much higher than that of $20 \mathrm{~nm}$ FluoSpheres ${ }^{\circledR}$. Images were analysed without background subtraction with a threshold set at $100 \%$ for both channels. The area of overlap was measured and the data exported into Excel. In addition, co-localization was determined using the Metamorph plugin CORRPLOT. After putting the threshold at $100 \%$ for the red channel and for the green 
channel the correlation of both signals was analysed. 50 cells were analysed for each particle.

\section{Lysosomal membrane integrity}

As positive control for lysosomal damage and interference with lysosome function chloroquine was used. After exposure for $24 \mathrm{~h}$ to $20 \mathrm{~nm}$ and $200 \mathrm{~nm}$ CPS, to negative controls (medium) and to positive controls (25 $\mu \mathrm{M}$ chloroquine, Sigma-Aldrich) cells were washed and loaded with $1 \mu \mathrm{M}$ Acridine Orange (Sigma-Aldrich) in PBS for 30 min at $37^{\circ} \mathrm{C}$. After rinse in PBS cells fluorescence was determined at a FLUOstar Optima (BMG Labortechnik) with $485 \mathrm{~nm} / 520 \mathrm{~nm}$ for the green and $584 \mathrm{~nm} / 612 \mathrm{~nm}$ for the red channel. The ratio of the signal in the red to the green channel was determined.

Alternatively, Lucifer yellow was used for assessment of lysosomal integrity. Cells were loaded with $0.1 \mathrm{mg} / \mathrm{ml}$ Lucifer yellow dilithium salt (Sigma) in culture medium at $37^{\circ} \mathrm{C}$ for $16 \mathrm{~h}$ prior to the exposure to the particles. Incubation with $100 \mu \mathrm{M}$ chloroquine was used as positive control. Images were taken with a LSM510 Meta confocal laser scanning microscope (Zeiss) with ex $405 \mathrm{~nm} /$ em LP $505 \mathrm{~nm}$.

\section{Assessment of lysosome function/pH}

LysoSensor $^{\text {mix }}$ Green DND-189 (Invitrogen), an acidotropic probe, which accumulates in acidic compartments of cells as a result of protonization, was used at $1 \mu \mathrm{M}$ for 5 min at $37^{\circ} \mathrm{C}$, according to the user manual. Accumulation in an acidic environment results in a $\mathrm{pH}$-dependent increase in fluorescence. Staining performed after preincubation for $4 \mathrm{~h}$ with CPS of different sizes was compared to cells preincubated in medium only. Quantification was performed at a FLUOstar Optima (BMG Labortechnik) with $485 \mathrm{~nm} / 520 \mathrm{~nm}$ and pictures were taken with a LSM510 Meta confocal laser scanning microscope (Zeiss) with ex 488/em BP 505-550.

Lysosome/Cytotoxicity Dual staining Kit (Cayman), as indicator for perturbation of lysosome function, was used as indicated by the producer. The membrane permeable 4-nitro-7-(1-piperazinyl)-2,1,3-benzoxadiazole (NBZ-PZ) reacts with carboxylic acids in the lysosome and fluorescence increases in an acid environment. Propidium iodide identifies cells with loss of membrane integrity. Chloroquine was used at a concentration of $25 \mu \mathrm{M}$ as positive control. Data were acquired at a FLUOstar Optima (BMG Labortechnik) with $485 \mathrm{~nm} / 520 \mathrm{~nm}$ for the green and $584 \mathrm{~nm} / 612 \mathrm{~nm}$ for the red channel.

\section{Assessment of lysosome function/lysosomal enzymes Cathepsin B activity}

For detection in lysed cells the Cathepsin B Activity Assay Kit (PromoKine) with Ac-Arg-Arg labelled with amino-4trifluoromethyl coumarine (Ac-RR-AFC) as substrate was used according to the instructions given in the User Manual. Fluorescence was measured at a FLUOstar Optima (BMG Labortechnik) using a $400 \mathrm{~nm} / 505 \mathrm{~nm}$ filter set.

For the detection of cathepsin B activity in-situ, cells were rinsed in $\mathrm{PBS}$ and exposed to the $\mathrm{CV}-(\mathrm{RR})_{2}$ substrate of the BIOMOL CV- Cathepsin B Detection Kit (Eubio). The stem solution in DMSO was diluted 1:5000 with medium and added for $20 \mathrm{~min}$ at $37^{\circ} \mathrm{C}$. After this incubation, cells were rinsed in PBS and fluorescence quantified by fluorometric reading on a FLUOstar Optima $(584 \mathrm{~nm} / 612 \mathrm{~nm})$. Thereafter, cells were fixed in $4 \%$ formalin and processed for co-labelling with LAMP1 antibody. In several experiments, fluorescence data of unfixed and fixed samples were compared to exclude an influence of the fixation on the result $25 \mu \mathrm{M}$ chloroquine was used as positive control.

\section{Lysosomal sulfatases}

Activity in situ was assessed using the MarkerGene ${ }^{\mathrm{Tw}}$ LysoLife $^{\mathrm{mx}}$ Lysosomal Sulfatase Detection Kit (Eubio). After removal of the medium, the cells were washed once in PBS and incubated with the SulfGreen substrate $(1.25 \mathrm{mM})$ in $\mathrm{PBS}$ for $4 \mathrm{~h}$ at $37^{\circ} \mathrm{C}$. After this incubation, cells were rinsed in PBS and fluorescence quantified by fluorometric reading on a FLUOstar Optima (485 nm/ $520 \mathrm{~nm}$ ). Thereafter, cells were fixed in $4 \%$ formalin and processed for co-labelling with LAMP-1 antibody. In several experiments, fluorescence data of unfixed and fixed samples were compared to exclude an influence of the fixation on the result. $25 \mu \mathrm{M}$ chloroquine was used as positive control.

\section{Amount of lysosomes}

For identification of changes in the endosomallysosomal system immunoreactivity against the major lysosomal membrane glycoprotein LAMP-1, located in the membrane of late endosomes and lysosomes [62], was used. Cells were fixed in $4 \%$ formalin for $10 \mathrm{~min}$ at $\mathrm{RT}$, washed three times in PBS, blocked for $30 \mathrm{~min}$ in $1 \%$ goat serum and incubated with the anti LAMP-1 antibody (1:1000, rabbit, Abcam) for $1 \mathrm{~h}$ at RT. For visualization of the antibody binding, different secondary antibodies were used. Alexa 488-labelled secondary antibody (1:200, goat anti-rabbit IgG, Invitrogen) in costaining experiments with cathepsin B activity and DyLight 594-labelled secondary antibody (1:200, goat anti-rabbit IgG, ThermoScientific) in combination with lysosomal sulfatase activity was added for $30 \mathrm{~min}$ at RT. For microscopical images cells were counterstained with $1 \mu \mathrm{g} / \mathrm{ml}$ Hoechst33342 for $15 \mathrm{~min}$ at RT. Data were acquired at a FLUOstar Optima (BMG Labortechnik). The following filter settings were used for the fluorometric evaluation: $485 \mathrm{~nm} / 520 \mathrm{~nm}$ (SulfGreen substrate, LAMP-1 green detection), $584 \mathrm{~nm} / 612 \mathrm{~nm}$ (cathepsin B substrate 
$\mathrm{CV}-(\mathrm{RR})_{2}$, LAMP-1, red detection). For documentation of the staining, pictures were taken at a LSM510 Meta confocal laser scanning microscope (Zeiss) with 405/BP 420-480 for the blue channel, 488/BP 505-550 for the green channel (LysoSensor ${ }^{\mathrm{Tm}}$, LAMP-1 detected with Alexa 488-labelled secondary antibody) and a 543/LP 560 for the red channel $\left(\mathrm{CV}-(\mathrm{RR})_{2}\right.$, LAMP-1 detected with DyLight 594-labelled secondary antibody).

\section{Statistics}

For Data Analysis of microarrays CEL files were imported into Partek Genomic Suite6.4 software (Partek Inc) and robust multi-chip average (RMA) normalized (including background correction, quantilequintile normalization across all arrays, median polished summarization based on log transformed expression values). For detection of differentially expressed genes analysis of variance (ANOVA) was performed and genes with FDR5\% and a fold change of at least 2 were considered to be significantly de-regulated.

All other data are represented as means \pm S.D from three to six experiments. Data were analyzed with one-way analysis of variance (ANOVA) followed by Tukey-HSD post hoc test for multiple comparisons (SPSS 19 software). Differences between two samples were analyzed by independent $t$-test and Levine's Test for Equality of Variances. Results with p-values of less than 0.05 were considered to be statistically significant.

\section{Additional files}

Additional file 1: Table S1. Analysis of gene de-regulation in cells
cultured in medium + 2\% FBS compared to cells in medium $+10 \%$
FBS according to biological processes. A. Up-regulated genes in $2 \%$
FBS compared to $10 \%$ FBS. B. Down-regulated genes in $2 \%$ FBS
compared to $10 \%$ FBS.
Additional file 2: Table S2.
Additional file 3: Figure S1. Staining of EAhy926 cells for lysosomal
integrity using Lucifer yellow. Controls show a punctate staining,
whereas cells treated with chloroquine show a diffuse cytoplasmic
staining. The staining pattern of cells treated with 20 mg/ml 20 nm and
200 nm carboxyl polystyrene particles (CPS) is similar to that of untreated
controls. scale bar: $20 \mu$ m. Figure 5 s: Confocal image of LysoSensor
(green) and cathepsin B substrate CV-(RR) 2 (red) double-stained EAhy926
cells. Co-localization of both staining is seen in yellow. In general more
structures with acid content stained with LysoSensor than those with
cathepsin B activity are seen. Arrows mark organelles with high cathepsin
B activity and arrowheads indicate acidic structures with low cathepsin B
activity. Scale bar: $10 \mu$ m.

\section{Competing interest}

The authors disclose any financial competing interests.

\section{Acknowledgements}

We thank Diana Mujk for lysosomal assays, Hannes Seidl for microarray analysis and Sandra Blass for physico-chemical characterization of the particles. Editing of English language by Gabriella Salas is gratefully acknowledged. This work was supported by the FP6 European integrated project NanoBiopharmaceutics, the Research and Technology Development in Project Cluster NANO-HEALTH and the Austrian Research Science Grant P22576-B18.

\section{Author details}

${ }^{1}$ Center for Medical Research, Medical University of Graz, Graz, Austria. ${ }^{2}$ Department of Internal Medicine, Division of Endocrinology and Nuclear Medicine, Medical University of Graz, Graz, Austria. ${ }^{3}$ Institute of Pharmaceutical Sciences, Department of Pharmaceutical Technology, Karl-Franzens-University of Graz, Graz, Austria.

\section{Authors' contributions}

EF: study design and writing of manuscript. CM, MA: experiments and data analysis. ER: particle characterization and draft of manuscript. EB: analysis of microarray data. TP: coordination and draft the manuscript. All authors read and approved the final manuscript.

Received: 20 February 2012 Accepted: 12 July 2012

Published: 12 July 2012

References

1. Nel A, Xia T, Madler L, Li N: Toxic potential of materials at the nanolevel. Science 2006, 311:622-627.

2. Migliore L, Coppede F: Environmental-induced oxidative stress in neurodegenerative disorders and aging. Mutat Res 2009, 674:73-84.

3. Ranft U, Schikowski T, Sugiri D, Krutmann J, Kramer U: Long-term exposure to traffic-related particulate matter impairs cognitive function in the elderly. Environ Res 2009, 109:1004-1011.

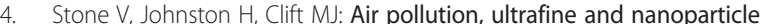
toxicology: cellular and molecular interactions. IEEE Trans Nanobiosci 2007, 6:331-340.

5. Lin P, Chen JW, Chang LW, Wu JP, Redding L, Chang H, Yeh TK, Yang CS, Tsai $\mathrm{MH}$, Wang $\mathrm{HJ}$, et al: Computational and ultrastructural toxicology of a nanoparticle, Quantum Dot 705, in mice. Environ Sci Technol 2008, 42:6264-6270

6. Yang RS, Chang LW, Wu JP, Tsai MH, Wang HJ, Kuo YC, Yeh TK, Yang CS, Lin $P$ : Persistent tissue kinetics and redistribution of nanoparticles, quantum dot 705, in mice: ICP-MS quantitative assessment. Environ Health Perspect 2007, 115:1339-1343

7. Chen J, Dong $X$, Zhao J, Tang G: In vivo acute toxicity of titanium dioxide nanoparticles to mice after intraperitioneal injection. J Appl Toxicol 2009, 29:330-337.

8. Fabian E, Landsiedel R, Ma-Hock L, Wiench K, Wohlleben W, van Ravenzwaay B: Tissue distribution and toxicity of intravenously administered titanium dioxide nanoparticles in rats. Arch Toxicol 2008 82:151-157

9. Lasagna-Reeves C, Gonzalez-Romero D, Barria MA, Olmedo I, Clos A Sadagopa Ramanujam VM, Urayama A, Vergara L, Kogan MJ, Soto C: Bioaccumulation and toxicity of gold nanoparticles after repeated administration in mice. Biochem Biophys Res Commun 2010, 393:649-655.

10. Oberdorster G, Ferin J, Lehnert BE: Correlation between particle size, in vivo particle persistence, and lung injury. Environ Health Perspect 1994 102(Suppl 5):173-179.

11. Mukae H, Vincent R, Quinlan K, English D, Hards J, Hogg JC, van Eeden SF: The effect of repeated exposure to particulate air pollution (PM10) on the bone marrow. Am J Respir Crit Care Med 2001, 163:201-209.

12. Ji JH, Jung JH, Kim SS, Yoon JU, Park JD, Choi BS, Chung YH, Kwon IH, Jeong J, Han BS, et al: Twenty-eight-day inhalation toxicity study of silver nanoparticles in Sprague-Dawley rats. Inhal Toxicol 2007, 19:857-871.

13. Rossi EM, Pylkkanen L, Koivisto AJ, Vippola M, Jensen KA, Miettinen M, Sirola K, Nykasenoja H, Karisola P, Stjernvall T, et al: Airway exposure to silicacoated $\mathrm{TiO} 2$ nanoparticles induces pulmonary neutrophilia in mice. Toxicol Sci 2010, 113:422-433.

14. Yin XJ, Dong CC, Ma JY, Antonini JM, Roberts JR, Stanley CF, Schafer R, Ma $J \mathrm{~K}$ : Suppression of cell-mediated immune responses to listeria infection by repeated exposure to diesel exhaust particles in brown Norway rats. Toxicol Sci 2004, 77.263-271.

15. Geiser M, Rothen-Rutishauser B, Kapp N, Schurch S, Kreyling W, Schulz H, Semmler M, Im Hof V, Heyder J, Gehr P: Ultrafine particles cross cellular membranes by nonphagocytic mechanisms in lungs and in cultured cells. Environ Health Perspect 2005, 113:1555-1560.

16. Rothen-Rutishauser BM, Schurch S, Haenni B, Kapp N, Gehr P: Interaction of fine particles and nanoparticles with red blood cells visualized with advanced microscopic techniques. Environ Sci Technol 2006, 40:4353-4359. 
17. Muhlfeld C, Gehr P, Rothen-Rutishauser B: Translocation and cellular entering mechanisms of nanoparticles in the respiratory tract. Swiss Med Wkly 2008, 138:387-391.

18. Sahay G, Alakhova DY, Kabanov AV: Endocytosis of nanomedicines. J Control Release 2010, 145:182-195

19. Doherty GJ, McMahon HT: Mechanisms of endocytosis. Ann Rev Biochem 2009, 78:857-902.

20. Chithrani BD, Ghazani AA, Chan WC: Determining the size and shape dependence of gold nanoparticle uptake into mammalian cells. Nano Lett 2006, 6:662-668.

21. Faklaris O, Joshi V, Irinopoulou T, Tauc P, Sennour M, Girard H, Gesset C, Arnault JC, Thorel A, Boudou JP, et al: Photoluminescent diamond nanoparticles for cell labeling: study of the uptake mechanism in mammalian cells. ACS Nano 2009, 3:3955-3962.

22. Goya GF, Marcos-Campos I, Fernandez-Pacheco R, Saez B, Godino J, Asin L, Lambea J, Tabuenca P, Mayordomo Jl, Larrad L, et al: Dendritic cell uptake of iron-based magnetic nanoparticles. Cell Biol Int 2008, 32:1001-1005.

23. Jaiswal JK, Mattoussi H, Mauro JM, Simon SM: Long-term multiple color imaging of live cells using quantum dot bioconjugates. Nat Biotechnol 2003, 21:47-51.

24. Nativo P, Prior IA, Brust M: Uptake and intracellular fate of surfacemodified gold nanoparticles. ACS Nano 2008, 2:1639-1644.

25. Rejman J, Oberle V, Zuhorn IS, Hoekstra D: Size-dependent internalization of particles via the pathways of clathrin- and caveolae-mediated endocytosis. Biochem J 2004, 377:159-169.

26. Stearns RC, Paulauskis JD, Godleski JJ: Endocytosis of ultrafine particles by A549 cells. Am J Respir Cell Mol Biol 2001, 24:108-115.

27. Olsson GM, Svensson I, Zdolsek JM, Brunk UT: Lysosomal enzyme leakage during the hypoxanthine/xanthine oxidase reaction. Virchows Archiv $B$ 1989, 56:385-391.

28. Maysinger D, Lovric J: Quantum dots and other fluorescent nanoparticles: quo vadis in the cell? Adv Exp Med Biol 2007, 620:156-167.

29. Moore MN, Readman JAJ, Readman JW, Lowe DM, Frickers PE, Beesley A: Lysosomal cytotoxicity of carbon nanoparticles in cells of the molluscan immune system: An in vitro study. Nanotoxicology 2009, 3:40-45.

30. Koehler A, Marx U, Broeg K, Bahns S, Bressling J: Effects of nanoparticles in Mytilus edulis gills and hepatopancreas - a new threat to marine life? Mar Environ Res 2008, 66:12-14

31. Holz FG, Schutt F, Kopitz J, Eldred GE, Kruse FE, Volcker HE, Cantz M: Inhibition of lysosomal degradative functions in RPE cells by a retinoid component of lipofuscin. Invest Ophthalmol Vis Sci 1999, 40:737-743.

32. Garnett MC, Kallinteri P: Nanomedicines and nanotoxicology: some physiological principles. Occup Med 2006, 56:307-311.

33. Frese MA, Schulz S, Dierks T: Arylsulfatase G, a novel lysosomal sulfatase. J Biol Chem 2008, 283:11388-11395.

34. Greiner-Tollersrud O, Berg T: Lysosomal storage disorders. In Lysosomes. Edited by Saftig P. New York: Springer Science, Landes Bioscience; 2005:60-73.

35. Anderson N, Borlak J: FEBS Lett. Drug-induced phospholipidosis 2006 580:5533-5540.

36. Fröhlich E, Meindl C, Roblegg E, Griesbacher A, Pieber TR: Cytotoxicity of nanoparticles is influenced by size, proliferation and embryonic origin of the cells used for testing. Nanotoxicology 2012, 6:424-439.

37. Fröhlich E, Samberger C, Kueznik T, Absenger M, Roblegg E, Zimmer A Pieber TR: Cytotoxicity of nanoparticles independent from oxidative stress. J Toxicol Sci 2009, 34:363-375.

38. Bhattacharyya S, Solakyildirim K, Zhang Z, Linhardt RJ, Tobacman JK: Chloroquine reduces arylsulphatase $B$ activity and increases chondroitin4-sulphate: implications for mechanisms of action and resistance. Malar $J$ 2009, 8:303

39. MacGregor RR, Hamilton JW, Kent GN, Shofstall RE, Cohn DV: The degradation of proparathormone and parathormone by parathyroid and liver cathepsin B. J Biol Chem 1979, 254:4428-4433.

40. http://www.fda.gov/ohrms/dockets/ac/06/briefing/2006-4235B2-, 01 01 AbraxisBioscience-background.pdf.

41. http://www.pharmazie.com/graphic/A/42/1-24242.pdf.

42. Uchida M, Willits $D$, Muller $K$, Willis $A$, Jackiw $L$, Jutila $M$, Young $M$, Porter $A$ Douglas T, Uchida M, Willits D, Muller K, Willis A, Jackiw L, Jutila M, Young $M$, Porter A, Douglas $T$ : Intra-cellular distribution of macrophage targeting ferritin iron oxide nano-composite. Adv Mater 2009, 21:458-462.
43. Hasan NM, Adams GE, Joiner MC: Effect of serum starvation on expression and phosphorylation of PKC-alpha and p53 in V79 cells: implications for cell death. Int J Cancer 1999, 80:400-405.

44. Mengual Gomez DL, Belaich MN, Rodriguez VA, Ghiringhelli PD: Effects of fetal bovine serum deprivation in cell cultures on the production of Anticarsia gemmatalis multinucleopolyhedrovirus. BMC Biotechnol 2010, 10:68

45. Oya N, Zolzer F, Werner F, Streffer C: Effects of serum starvation on radiosensitivity, proliferation and apoptosis in four human tumor cell lines with different p53 status. Strahlenther Onkol 2003, 179:99-106.

46. Zetterberg A, Larsson O: Kinetic analysis of regulatory events in G1 leading to proliferation or quiescence of Swiss $3 \mathrm{~T} 3$ cells. Proc Natl Acad Sci USA 1985, 82:5365-5369.

47. Zetterberg A, Skold O: The effect of serum starvation on DNA, RNA and protein synthesis during interphase in L-cells. Exp Cell Res 1969. 57:114-118.

48. Lai SK, Hida K, Man ST, Chen C, Machamer C, Schroer TA, Hanes J: Privileged delivery of polymer nanoparticles to the perinuclear region of live cells via a non-clathrin, non-degradative pathway. Biomaterials 2007, 28:2876-2884

49. Al-Rawi M, Diabate S, Weiss C: Uptake and intracellular localization of submicron and nano-sized $\mathrm{SiO}(2)$ particles in HeLa cells. Arch Toxicol 2011, 85:813-826.

50. He Q, Zhang Z, Gao Y, Shi J, Li Y: Intracellular localization and cytotoxicity of spherical mesoporous silica nano- and microparticles. Small 2009, 5:2722-2729.

51. Silver J, Ou W: Photoactivation of quantum dot fluorescence following endocytosis. Nano Lett 2005, 5:1445-1449.

52. Lévy R, Shaheen U, Cesbron Y, Sée V: Gold nanoparticles delivery in mammalian live cells: a critical review. Nano Rev 2010, 1

53. Asati A, Santra S, Kaittanis C, Perez JM: Surface-charge-dependent cell localization and cytotoxicity of cerium oxide nanoparticles. ACS Nano 2010, 4:5321-5331.

54. van Dyke R: part III The lysosome in its cytoplasmic environment. Acidification of endosomes and lysosomes. Lysosomal membrane bodies. In Subcellular Biochemistry, Vol 27 Biology of the lysosome. 23rd edition. Edited by Lloyd J, Mason R. London, New York: Plenum Press; 1996.

55. Held P, Newick K, Shen D, Patton W: Automated Detection of DrugInduced Lysosomal Cytotoxicity - Automation of the Lyso-ID ${ }^{\circledR}$ Red Assay Using the EL406 ${ }^{\mathrm{TM}}$ Combination Washer Dispenser. Lab Manager Magazine 2010.

56. Ishiguro K, Ando T, Goto H: Novel application of 4-nitro-7-(1-piperazinyl)2,1,3-benzoxadiazole to visualize lysosomes in live cells. Biotechniques $2008,45: 467-468$.

57. Swain WA, O'Byrne KJ, Faux SP: Activation of p38 MAP kinase by asbestos in rat mesothelial cells is mediated by oxidative stress. Am J Physiol Lung Cell Mol Physiol 2004, 286:L859-865.

58. Oh YK, Swanson JA: Different fates of phagocytosed particles after delivery into macrophage lysosomes. J Cell Biol 1996, 132:585-593.

59. Patzold S, Schmidt A, Seidel A: Loss of cathepsin B activity in alveolar macrophages after in vitro quartz phagocytosis. J Toxicol Environ Health 1993, 40:547-554.

60. Xia T, Kovochich M, Brant J, Hotze M, Sempf J, Oberley T, Sioutas C, Yeh II, Wiesner MR, Nel AE: Comparison of the abilities of ambient and manufactured nanoparticles to induce cellular toxicity according to an oxidative stress paradigm. Nano Lett 2006, 6:1794-1807.

61. Mayer A, Vadon M, Rinner B, Novak A, Wintersteiger R, Fröhlich E: The role of nanoparticle size in hemocompatibility. Toxicology 2009, 258:139-147.

62. D'Souza MP, August JT: A kinetic analysis of biosynthesis and localization of a lysosome-associated membrane glycoprotein. Arch Biochem Biophys 1986, 249:522-532

doi:10.1186/1743-8977-9-26

Cite this article as: Fröhlich et al:: Action of polystyrene nanoparticles of different sizes on lysosomal function and integrity. Particle and Fibre Toxicology 2012 9:26. 